\title{
Population dynamics of two suspension-feeding bivalves on a sheltered beach in southeastern Brazil
}

\author{
Gustavo Mattos • Ricardo S. Cardoso
}

Received: 11 May 2011/Revised: 11 October 2011/Accepted: 18 October 2011/Published online: 9 November 2011

(C) Springer-Verlag and AWI 2011

\begin{abstract}
The population biology and secondary production of the bivalves Anomalocardia brasiliana (Gmelin, 1791) and Diplodonta punctata (Say, 1822) were studied on a sheltered beach on the southeast coast of Brazil (Flexeiras Beach) between December 2006 and February 2009. Six transects were established perpendicular to the shoreline. Along each transect, sampling units (SUs) were extracted every $3 \mathrm{~m}$, with a $0.04 \mathrm{~m}^{2}$ metal sampler and to a depth of $25 \mathrm{~cm}$, from the base of the boulder wall until $9 \mathrm{~m}$ below the waterline during low tide. The abundances of A. brasiliana and D. punctata were inversely correlated over time. The populations differed in several aspects: (1) A. brasiliana occupied mainly the upper levels, whereas D. punctata occupied the lower level of the beach; (2) total abundance, growth rate, and production were higher for A. brasiliana; and (3) mortality and turnover rate were higher for D. punctata. The differences in growth, mortality, and production parameters may be associated with a difference in the species' abilities to exploit resources.
\end{abstract}

Keywords Growth · Mortality - Secondary production · Anomalocardia brasiliana - Diplodonta punctata. Sepetiba Bay

Communicated by H.-D. Franke.

\section{G. Mattos $(\bowtie)$}

Programa de Pós-Graduação em Ecologia, Departamento de Ecologia, Universidade Federal do Rio de Janeiro (UFRJ), Rio de Janeiro, RJ CEP 21949-900, Brazil

e-mail: gustavo.mattos@globo.com

G. Mattos - R. S. Cardoso

Laboratório de Ecologia Marinha, Departamento de Ecologia e Recursos Marinhos, Universidade Federal do Estado do Rio de Janeiro (UNIRIO), Rio de Janeiro, RJ CEP 22290-240, Brazil

\section{Introduction}

Knowledge of the ecology of sandy beach macrofauna along the exposed-sheltered gradient is clearly uneven worldwide. Several studies have focused on community ecology and population dynamics of macrofauna from exposed beaches (Defeo and McLachlan 2005, 2011), while sheltered beaches have been a historically neglected area of sandy-beach ecology (Cardoso et al. 2011). Surprisingly, few studies have analyzed population parameters of sheltered beach macrofauna (Denadai et al. 2004; Abrahão et al. 2010), even though these environments support a high diversity of species (Dexter 1992).

Mollusks are important components of the sheltered beach macrofauna, show different life styles (epifaunal and infaunal) and feeding habits (suspension-, deposit feeders, scavengers, and predators), and consequently play a key role in macrofauna ecology (Jaramillo et al. 2007). Among mollusks, bivalves usually dominate the macrofauna biomass on sheltered beaches (McLachlan and Brown 2006), affecting the vertical distribution and stability of the sediments (Hall 1994), the nutrient fluxes from the sediment to the water column (Michaud et al. 2006), and the oxygen availability (Michaud et al. 2005) by means of their burrowing habit.

Many species of bivalves coexist on sheltered beaches, including the suspension-feeding bivalves Anomalocardia brasiliana (Veneridae) and Diplodonta punctata (Ungulinidae) (Cardoso et al. 2011). A. brasiliana has a wide geographical distribution, from the West Indies to Uruguay (Rios 1994). This species is commonly found in the intertidal beaches, estuaries, and salt marshes, and it is considered eurythermal and euryhaline (Shaeffer-Novelli 1976), being adapted to live at low concentrations of dissolved oxygen and in the presence of hydrogen sulfide 
(Hiroki 1977). This species is exploited by commercial and recreational harvesters on the Brazilian coast because of its high abundance and protein value (Arruda-Soares et al. 1982). Previous studies have addressed its demography and growth (Monti et al. 1991); embryonic, larval and postlarval development (Mouëza et al. 1999); functional morphology (Narchi 1972); osmotic regulation (Leonel et al. 1983); and depuration effects on trace metals (WallnerKersanach et al. 1994). Already Diplodonta punctata has a distribution from North Carolina to Chile, where it is found in sandy and muddy bottoms (Rios 1994). There is only a study about biological aspects of D. punctata (Domaneschi 1979).

In the present study, we analyzed the population biology of the two bivalves Anomalocardia brasiliana and Diplodonta punctata in a sheltered beach located in southeastern Brazil. Like other suspension-feeding intertidal invertebrates, A. brasiliana and D. punctata constitute a major link in the energy flow between producers and higher trophic levels (DeLancey 1989), beyond their key role in recycling nutrients through their excretions (Bergamino et al. 2011). Thus, knowledge of the spatial distribution and life-history traits, the ecological relationship with other suspension feeders, and the contribution of these species to the productivity of the macrofaunal community is fundamental for an understanding and proper management of the studied sheltered beach ecosystem. We evaluated (1) the spatial and temporal distribution of the two bivalve species and (2) their population parameters and secondary production.

\section{Materials and methods}

Study site and sampling

Flexeiras Beach is a sheltered beach located in the inner Sepetiba Bay, southeastern Brazil $\left(22^{\circ} 56^{\prime} \mathrm{S}, 43^{\circ} 53^{\prime} \mathrm{W}\right)$. The beach is about $350 \mathrm{~m}$ long and about $30 \mathrm{~m}$ wide, and has a microtidal regime with a mean tidal range of $1.5 \mathrm{~m}$.

Samples were taken monthly in the intertidal zone between December 2006 and February 2009. They were taken along six transects perpendicular to the shoreline. Along each transect, sampling units (SUs) were extracted during low tide every $3 \mathrm{~m}$, with a $0.04-\mathrm{m}^{2}$ metal sampler, and to a depth of $25 \mathrm{~cm}$, from the boulder wall until $9 \mathrm{~m}$ below the waterline (during low-tide spring level). Each sample was sieved through a $0.5-\mathrm{mm}$ mesh, and the retained material was taken to the laboratory.

Sediment samples for particle-size analysis were collected with a $3.5-\mathrm{cm}$ diameter corer to a depth of $15 \mathrm{~cm}$ at lower, middle, and upper strata of two transects. Samples were oven-dried at $70^{\circ} \mathrm{C}$ and passed through a series of sieves $(-2.5$ to 4.0 phi) in order of size, to determine the mean grain size (Folk and Ward 1957).

Laboratory procedures

The collected biological material was sorted and preserved in $10 \%$ formalin. Anomalocardia brasiliana and Diplodonta punctata individuals were measured with a vernier caliper along the greatest valve length, and the individuals of each species were grouped into 1-mm (A. brasiliana) and $0.5-\mathrm{mm}$ (D. punctata) size classes. All soft parts of the individuals were removed and dried at $70^{\circ} \mathrm{C}$ until constant weight, weighed, ashed in a muffle furnace for $4 \mathrm{~h}$ at $600^{\circ} \mathrm{C}$, and re-weighed.

\section{Data analysis}

$t$ Test was used to compare the monthly abundances of A. brasiliana and D. punctata. A multi-factorial nested ANOVA was used to test significant differences in abundance in space (strata factor with three levels) and time (year with two levels; season with four levels; and month with twelve levels) for A. brasiliana and D. punctata, using months nested in seasons. One-way ANOVA was performed to compare the spatial variability of mean grain size. Tukey's honest significant difference (HSD) test was used a posteriori to assess significant differences. Normality and homogeneity of variance was assessed using the Cochran test, and where necessary, data were appropriately transformed. When variances were to be significantly heterogeneous even after transformation, untransformed data were analyzed and a significance level of 0.01 was adopted (Underwood 1981). Relationship between A. brasiliana and D. punctata densities were modeled by linear and nonlinear fitting, and the best explained relationship was selected based on $R^{2}$.

Population parameters

\section{Growth}

For growth analysis, the ELEFAN (electronic frequency analysis) routine of the FISAT package (FAO ICLARM Stock Assessment Tools) was used. This approach assumes that growth is described by the von Bertalanffy growth function modified for seasonality (Gayanilo et al. 1996) as:

$L_{t}=L_{\infty}\left[1-\mathrm{e}^{[-K(t-t o)+(K C / 2 \pi) \sin 2 \pi(t-W P)-(K C / 2 \pi) \sin 2 \pi(t o-W P)]}\right]$

where $L_{t}$ is length $(\mathrm{mm})$ at time $t ; L_{\infty}$ is the theoretical maximum length attained by the species; $K$ is the curvature parameter; $C$ is a constant for the amplitude of oscillation in seasonal growth; $t_{o}$ is the theoretical age at zero length; 
and $W P$ is the winter point (i.e., period of growth reduction, expressed as a decimal fraction of the year). The growth index phi prime $\left(\Phi^{\prime}\right)$, defined as: $\Phi^{\prime}=2 \log _{10}\left(L_{\infty}\right)+$ $\log _{10} K$ (Pauly and Munro 1984), was used to measure growth performance. This criterion was chosen because the negative correlation between $K$ and $L_{\infty}$ (Pauly and Munro 1984) invalidates comparisons based on individual parameters. Life span $\left(t_{\max }\right)$ was estimated by growth parameters of VBGF and on the basis of the length representing the 99th percentile of the population, $L_{99 \%}$ (Sparre et al. 1989).

\section{Mortality}

The instantaneous mortality rate $(Z)$ was calculated for each species by the single negative exponential model and by the length-converted catch curve method (Pauly et al. 1995) of the FISAT program (Gayanilo et al. 1996). The estimation of $\mathrm{Z}$ was given by:

$\ln (N)=g-Z t$

where $N$ is the number of individuals; $g$ is the regression intercept; $Z$ is the unbiased mortality estimated in a module, and $t$ is the estimated age in each cohort (Pauly et al. 1995). The annual mortality rate $(A)$ was obtained through the expression: $A=1-\mathrm{e}^{-Z}$, according to Ricker (1975). An ANCOVA discriminated by species was used to compare instantaneous mortality, with age as the covariate.

\section{Secondary production}

The relationship between length and ash-free dry mass (AFDM) was estimated by the power function:

$$
W=a L^{b}
$$

where $W$ is the mean monthly AFDM per length class $(\mathrm{g})$; $L$ is the length of the size class ( $\mathrm{mm})$; and $a$ and $b$ are constants. To compare the length-weight function between species, an ANCOVA was performed with length as covariate. Data were linearized (log-transformed) to fulfill ANCOVA assumptions.

Production was estimated by the weight-specific growth rate method. In these calculations, it is necessary to measure growth or mortality rates as a function of size and season and to sum the values throughout the year for each length class (Crisp 1984). Production was given by the equation:

$P=\Sigma \Sigma f_{i} G_{i} w_{i} \Delta t$

where $f$ is the mean number of individuals of this length class existing in the population during the time interval $\Delta t$; $G_{i}$ is the specific growth rate in weight of length class $i$; and $w_{i}$ is the mean weight of the length class. $G_{i}$ can be obtained by:
$\left.G_{i}=b K\left[L_{\infty} / L_{i}\right)-1\right]$

where $b$ is the exponent of the length-weight relationship; $K$ and $L_{\infty}$ are VBGF parameters; and $L_{i}$ is the mean length in length class $i$. Annual mean biomass was calculated as:

$B=\Sigma \Sigma f_{i} w_{i} \Delta t$

\section{Results}

Physical characterization

The mean grain size ranged from $0.25 \mathrm{~mm}$ (medium sand) to $1.30 \mathrm{~mm}$ (very coarse sand). One-way ANOVA indicated significant differences of mean grain size among strata $(F=4.57 ; d f=2 / 159 ; P<0.05)$, and Tukey test detected differences only in upper strata $(P<0.05)$.

Population structure

A total of 8,887 individuals of Anomalocardia brasiliana and 4,482 of Diplodonta punctata were measured during the field survey. The mean monthly abundance of $A$. brasiliana (289.40 ind $\mathrm{m}^{-2}$ ) was significantly higher than that of D. punctata (77.96 ind $\left.\mathrm{m}^{-2}\right)(T=11.30 ; d f=322$; $P<0.001)$. Nested ANOVA indicated significant differences between years for $A$. brasiliana $(F=18.22$; $d f=$ $1 / 255 ; P \ll 0.01)$. Abundance was significantly higher for the first year than the second one (Tukey's HSD; $P<0.05)$. For $D$. punctata, nested ANOVA indicated significant differences among seasons $(F=4.38 ; d f=$ $3 / 255 ; P<0.01)$. Abundance was significantly higher in winter than others seasons (Tukey's HSD; $P<0.05$ ) (Table 1). The high standard errors in monthly abundance of species suggest a clumped distribution of individuals (Fig. 1).

Anomalocardia brasiliana abundance was inversely correlated with that of Diplodonta punctata over time (exponential model; $R^{2}=0.1372$ ) (Fig. 2). The highest abundances were observed in the middle and lower strata for A. brasiliana and D. punctata, respectively $\left(F_{A \text {. brasiliana }}=\right.$ $38.41 ; d f=2 / 255 ; P \ll 0.01 ; F_{D}$. Punctata $=93.07 ; d f=$ 2/255; $P \ll 0.01$ ) (Table 1; Fig. 3).

\section{Growth}

The lengths of the smallest individuals were 2.52 (June 2008) and $2.82 \mathrm{~mm}$ (December 2008) and of the largest ones 36.57 (September 2008) and $19.24 \mathrm{~mm}$ (July 2007) for A. brasiliana and D. punctata, respectively. $L_{\infty}$ and $K$ varied between the species, resulting in a different growth performance index $\left(\Phi^{\prime}\right)$ (Fig. 4). Parameter $C$ (degree of seasonal variation) was higher in A. brasiliana 
Table 1 Multi-factorial nested ANOVA defined by space (strata) and time (year, season, and month)

\begin{tabular}{lrrrr}
\hline Factor & $d f$ & \multicolumn{1}{l}{ SS } & $F$ ratio & $P$ value \\
\hline $\begin{array}{l}\text { Anomalocardia brasiliana } \\
\text { Strata }\end{array}$ & 2 & $10,681,189$ & 38.4116 & $\mathbf{0 . 0 0 0 0 0 0}$ \\
Year & 1 & $2,533,761$ & 18.2238 & $\mathbf{0 . 0 0 0 0 2 8}$ \\
Season & 3 & 235,827 & 0.5654 & 0.638301 \\
Month (Season) & 8 & $1,812,599$ & 1.6296 & 0.116649 \\
Residual & 255 & $35,454,176$ & & \\
Diplodonta punctata & & & & \\
Strata & 2 & $6,422,402$ & 93.0675 & $\mathbf{0 . 0 0 0 0 0 0}$ \\
Year & 1 & 66 & 0.0019 & 0.965266 \\
Season & 3 & 453,322 & 4.3794 & $\mathbf{0 . 0 0 5 0 0 5}$ \\
Month (Season) & 8 & 479,530 & 1.7372 & 0.090203 \\
Residual & 255 & $8,798,518$ & & \\
\hline
\end{tabular}

Significant terms of interest $(\alpha=0.01)$ are highlighted in bold

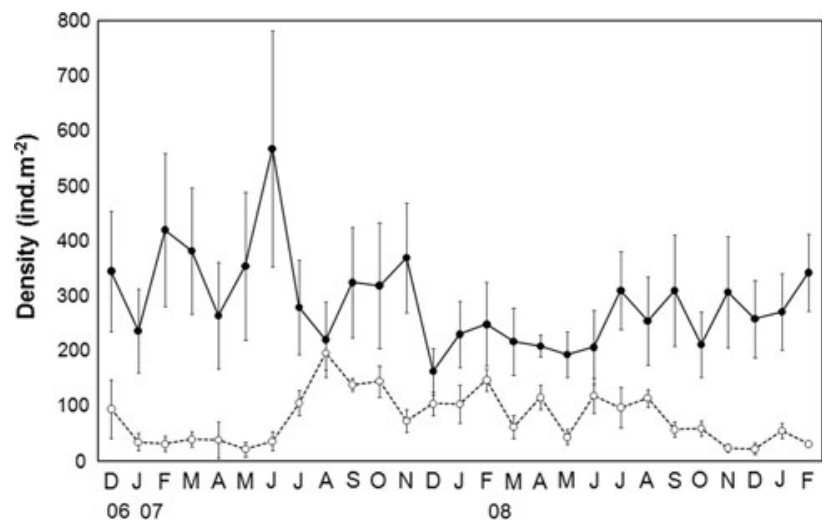

Fig. 1 Mean monthly density (ind $\mathrm{m}^{-2} \pm \mathrm{SE}$ ) of Anomalocardia brasiliana (black circles) and Diplodonta punctata (white circles) at Flexeiras Beach

than $D$. punctata, although both indicated a moderate oscillation in growth. Values of WP (point of lowest growth rate during the year) were close for the two bivalves, indicating lowest growth at the end of April and mid-February for A. brasiliana and D. punctata, respectively. The life span $\left(t_{\max }\right)$ of $A$. brasiliana was longer (2.64 years) than that of D. punctata (1.63 years) (Table 2).

\section{Mortality}

The mortality rate of $D$. punctata $\left(3.53\right.$ year $^{-1}$ ) was significantly higher than that of A. brasiliana $\left(3.17\right.$ year $\left.^{-1}\right)$ $(F=57.81 ; d f=1 / 36 ; P<0.001)$ (Fig. 5). The annual finite mortality rates $(A)$ were 0.96 and 0.97 year $^{-1}$ for A. brasiliana and $D$. punctata, respectively (Table 3 ).

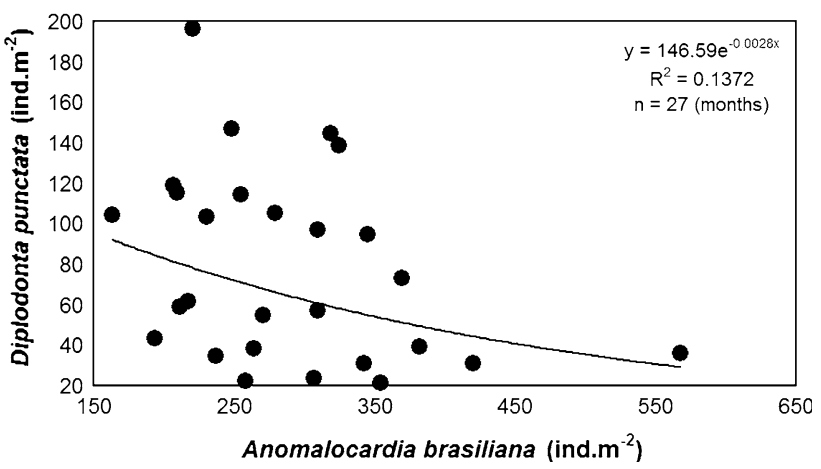

Fig. 2 Exponential model between A. brasiliana and D. punctata abundances (ind $\mathrm{m}^{-2}$ ) at Flexeiras Beach

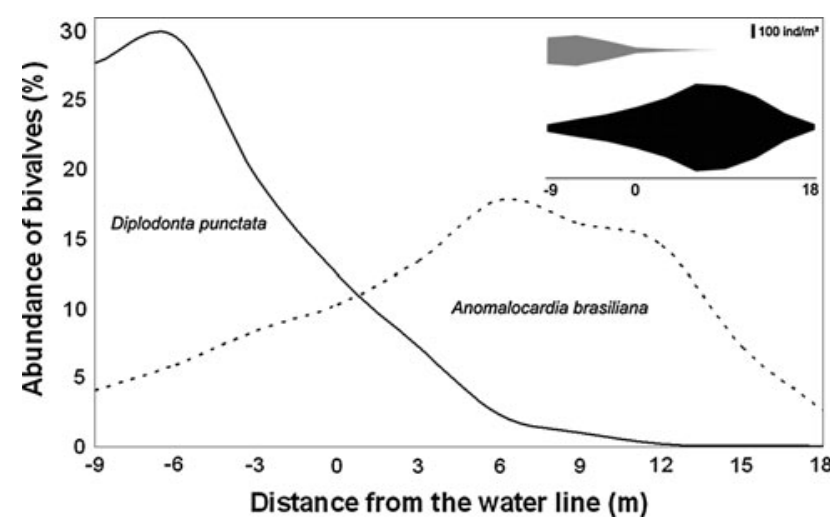

Fig. 3 Across-shore spatial distribution of abundance (\%) of Anomalocardia brasiliana and Diplodonta punctata. The zero value on the horizontal axis represents the waterline, and the negative and positive values indicate a downshore and an upshore direction, respectively. The zonation of the bivalves is shown in the upper section of the plot (A. brasiliana: black diagram, and D. punctata: gray one)

Secondary productivity

The regression equation between ash-free dry mass and length classes for the bivalve populations were expressed as: $W_{A \text {. brasiliana }}=\left(8 \times 10^{-6}\right) L^{2.95}(n=221 ; r=0.98$; $P<0.001)$ and $W_{D}$. punctata $=\left(4 \times 10^{-6}\right) L^{3.03}(n=186$; $r=0.97 ; \quad P<0.001)$. These data did not satisfy the ANCOVA assumptions (homogeneity of slopes and homogeneity of variances). The turnover rates $(P / B)$ were 1.27 and 1.82 year $^{-1}$ for A. brasiliana and D. punctata, respectively (Table 4$)$.

\section{Discussion}

The populations of two studied bivalves differed in several population parameters. A. brasiliana showed higher abundance, growth rate, and production than $D$. punctata. In contrast, D. punctata showed higher mortality and turnover 


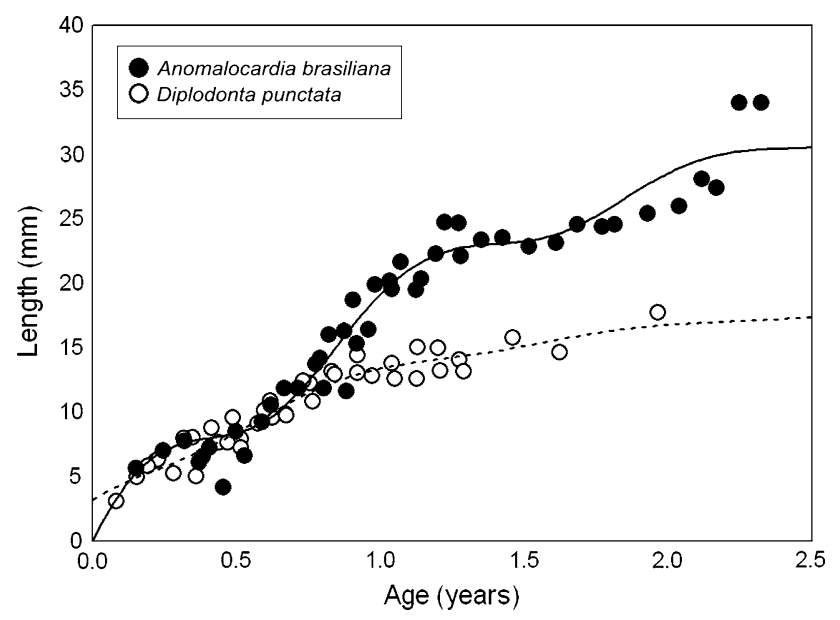

Fig. 4 Growth curves estimated for Anomalocardia brasiliana and Diplodonta punctata populations

Table 2 Growth parameters estimated by nonlinear least squares fit of the von Bertalanffy function of Anomalocardia brasiliana and Diplodonta punctata populations

\begin{tabular}{|c|c|c|c|c|}
\hline \multirow[t]{2}{*}{ Parameter } & \multicolumn{2}{|c|}{ Anomalocardia brasiliana } & \multicolumn{2}{|c|}{ Diplodonta punctata } \\
\hline & Mean $( \pm S E)$ & $P$ & Mean $( \pm \mathrm{SE})$ & $P$ \\
\hline$L_{\infty}(\mathrm{mm})$ & $37.62( \pm 3.70)$ & 0.000 & $18.48( \pm 2.55)$ & 0.000 \\
\hline$K\left(\right.$ year $\left.^{-1}\right)$ & $0.71( \pm 0.15)$ & 0.000 & $1.10( \pm 0.43)$ & 0.016 \\
\hline$C$ & $0.85( \pm 0.17)$ & 0.000 & $0.39( \pm 0.19)$ & 0.048 \\
\hline$W P$ & $0.41( \pm 0.03)$ & 0.000 & $0.20( \pm 0.11)$ & 0.076 \\
\hline$T_{0}$ (year) & $0.01( \pm 0.04)$ & 0.767 & $-0.16( \pm 0.12)$ & 0.177 \\
\hline$R$ & 0.98 & & 0.96 & \\
\hline$\Phi^{\prime}$ & 3.00 & & 2.58 & \\
\hline Smallest (mm) & 2.52 & & 2.82 & \\
\hline Largest (mm) & 36.57 & & 19.24 & \\
\hline$t_{\max }($ year $)$ & 2.64 & & 1.63 & \\
\hline
\end{tabular}

$L_{\infty}$ asymptotic length; $K$ curvature parameter; $C$ constant for the amplitude of seasonal oscillation of growth; WP point of lowest growth rate in the year; $T_{0}$ theoretical age at length $0 ; r$ correlation coefficient; $\Phi^{\prime}$ standard growth index (Pauly and Munro 1984); $t_{\max }$ life span

rate than A. brasiliana. Beyond differences in population parameters, these species showed a spatial and temporal segregation (Figs. 2, 3). In relation to temporal segregation, the negative correlation between the abundance of the species over time suggests that the abundance peaks of A. brasiliana coincide with periods of low abundance of D. punctata. All these differences could be caused by: (1) physiological process (A. brasiliana has a high ecological valence, see introduction); (2) environmental characteristics (desiccation, grain size); and/or (3) interaction between species (competition for space and food).

The bivalves showed a clear spatial segregation, with Anomalocardia brasiliana dominating the middle strata

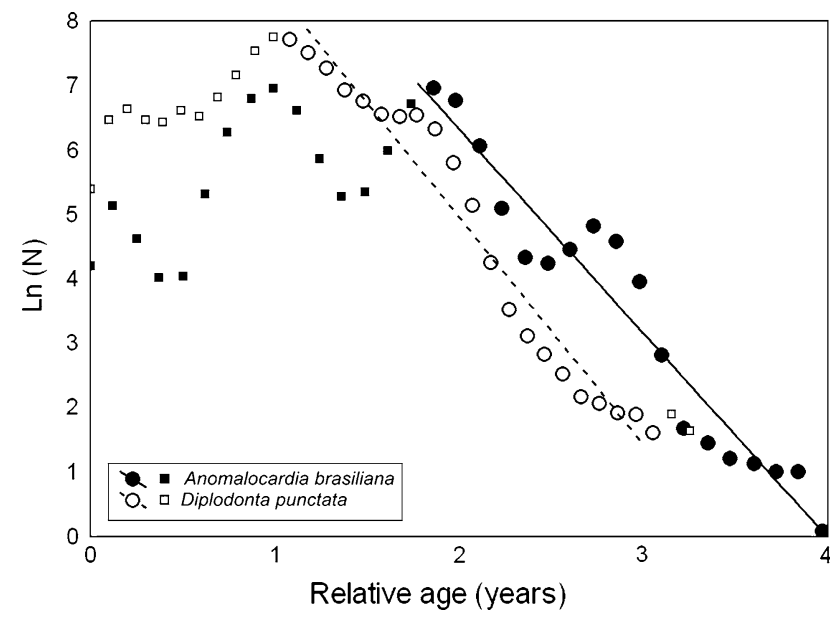

Fig. 5 Length-converted catch curves of Anomalocardia brasiliana and Diplodonta punctata. Points represented by squares were not used for fitting the linear regression

and Diplodonta punctata the lower strata of the beach (Fig. 3). This segregation could be associated with grain size; however, the middle and lower strata did not show statistically significant differences. So, others hypothesis are necessary to explain the spatial segregation of the bivalves.

The lower growth rate of $A$. brasiliana in relation to $D$. punctata can be related to a greater investment of energy in soft-part and shell production, since $A$. brasiliana individuals have more biomass and the shells are harder than in individuals of $D$. punctata. Furthermore, the largest theoretical maximum length was influenced, since $L_{\infty}$ and $K$ are inversely related. Therefore, there are other physiological and behavioral processes and plasticity in lifehistory traits (Brown 1996) that may explain the slower growth in A. brasiliana. The growth rate in both bivalves showed moderate seasonal variation, with the lowest growth rate $(W P)$ occurring in autumn and summer for $A$. brasiliana and $D$. punctata, respectively. The decrease in growth rate during the autumn for A. brasiliana can be explained by the breeding season. Narchi (1976) and Boehs (2000), studying gametogenesis in two A. brasiliana populations, observed intense spawning periods during autumn and spring, although both populations had a continuous gametogenic cycle. These results concorded with the decrease in the growth rate during autumn, when energy is transferred from somatic growth to the production of gametes (Moura et al. 2008). The decrease in growth rate of $D$. punctata can be explained by the same process, since in subtropical regions, the summer period is more favorable for reproduction. A recent study on the reproductive cycle of the venerid Callista chione from the southwestern Portuguese coast detected three spawning peaks: JanuaryMarch (winter), April-May (spring), and August-October 
Table 3 Mortality estimates $(Z)$ of Anomalocardia brasiliana and Diplodonta punctata populations and associated statistics (ANCOVA)

\begin{tabular}{lcclcc}
\hline Parameter & \multicolumn{2}{c}{ Anomalocardia brasiliana } & & \multicolumn{2}{c}{ Diplodonta punctata } \\
\cline { 2 - 3 } & Mean $( \pm \mathrm{SD})$ & $P$ & & Mean $( \pm \mathrm{SD})$ & $P$ \\
\hline$G$ & $12.66( \pm 0.62)$ & 0.000 & & $12.02( \pm 0.37)$ & 0.000 \\
$Z$ & $3.17( \pm 0.21)$ & 0.000 & & $3.53( \pm 0.17)$ & 0.000 \\
$R^{2}$ & 0.94 & & & 0.96 & \\
$N$ & 18 & & 21 &
\end{tabular}

ANCOVA $F_{1,36}=57.81 ; P<0.001$

ANCOVA homogeneity of slopes: $F_{1,35}=0.185 ; \quad P=0.182$. Homogeneity of variances: $F_{1,37}=0.167 ; P=0.685$

$G$ regression intercept; $R^{2}$ determination coefficient; $n$ number of points)

Table 4 Secondary production (P), biomass (B), and turnover rates $(P / B)$ of Anomalocardia brasiliana and Diplodonta punctata populations

\begin{tabular}{lcl}
\hline Parameter & $\begin{array}{l}\text { Anomalocardia } \\
\text { brasiliana }\end{array}$ & $\begin{array}{l}\text { Diplodonta } \\
\text { punctata }\end{array}$ \\
\hline $\mathrm{P}\left(\mathrm{g} \mathrm{AFDM} \mathrm{m}^{-2}\right.$ year $\left.^{-1}\right)$ & 11.60 & 0.79 \\
$\mathrm{~B}\left(\mathrm{~g} \mathrm{AFDM} \mathrm{m}^{-2}\right)$ & 9.14 & 0.43 \\
$P / B\left(\mathrm{year}^{-1}\right)$ & 1.27 & 1.82 \\
\hline
\end{tabular}

(summer); the population has no resting period and a new gametogenic cycle began in early November, immediately after these spawning episodes (Moura et al. 2008). According to these authors, the energy reserves are probably directed toward the recuperation of gonads, inducing a phase of slow growth in $C$. chione. Other studies have found similar seasonal growth patterns (Gaspar et al. 1999, 2004).

The higher mortality of $D$. punctata compared to A. brasiliana can be associated with the different zones occupied by the species and by differences the shell fragility (D. punctata has a thinner shell than A. brasiliana). Surprisingly, infaunal species that live submerged, as D. punctata, can be subject to greater predation pressure (by benthivorous fishes or crustraceans) than species that are exposed during low tide. Lee (1996) observed that the infaunal bivalve Tapes philippinarum suffered from higher predation pressure than Anomalocardia squamosa, associating this difference to the thinner shell of the former species. The annual mortality rates observed for A. brasiliana in the present study are higher than the mortality of 0.76 year $^{-1}$ found at $23^{\circ} \mathrm{S}$ (Salvador 2001), as well as than the values reported for other venerids: 0.47 year $^{-1}$ for Protothaca thaca at $36^{\circ} \mathrm{S}$ (Urban and Campos 1994), 0.27 year $^{-1}$ for Callista chione at $38^{\circ} \mathrm{N}$ (Metaxatos 2004), and 0.14 year $^{-1}$ for Eurhomalea exalbida at $54^{\circ} \mathrm{S}$ (Lomovasky et al. 2002). These differences may be related to latitude, because tropical regions show higher mortality rates compared to temperate regions (Ansell et al. 1978). According to Defeo and Cardoso (2004), the high mortality rate in subtropical beaches could be explained by a combination of rising metabolism at increasing temperature and insufficient food availability.

The higher production of $A$. brasiliana compared to D. punctata may be associated with the greater abundance of the venerid species. Because of the species' high abundance, the production of A. brasiliana accounts for a high percentage of the overall production of the local macrofaunal community. Among mollusks, A. brasiliana and the gastropod Cerithium atratum comprise more than $80 \%$ of all individuals in the macrofaunal community (Cardoso et al. 2011). On the other hand, the $P / B$ ratio calculated for $D$. punctata was higher than for $A$. brasiliana, a difference which possibly relates to the former species' lower individual body mass (Brey and Clarke 1993; Tumbiolo and Downing 1994) and longevity (Waters 1977; Robertson 1979). According to Robertson (1979), populations that show a high $P / B$ ratio consist of small individuals with a rapid growth rate and short life expectancy, while low $P / B$ values are associated with large individuals showing slow growth rate and long life expectancy.

We can conclude that the negative correlation between the abundance of these two bivalves over time suggest a potential competition for resources. Franke and Janke (1998) noted that suspension-feeders that co-occur naturally in marine environments are able to establish inter- and intraspecific competition relationships for food resources. The differences in growth, mortality, and production parameters can be associated with differences in the ability to exploit resources. Peterson and Black (1993), comparing suspension-feeders in different biogeographical regions, observed some reduction in growth at lower latitudes, probably resulting from increased competition for food. Furthermore, this study has contributed to our knowledge of the biology of an important fishery resource (A. brasiliana) and has produced additional information for future shell fishery management. Finally, the study has provided some knowledge on D. punctata, a species that belongs to a taxonomic group (family Ungulunidae) for which population studies were heretofore lacking.

Future research will focus on species with the same feeding habit (e.g., the suspension-feeders A. brasiliana and $D$. punctata), developing experimental approaches both in the field and the laboratory to estimate interactions between macrofauna species, measuring the degree of interactions and possible consequences for population dynamics.

Acknowledgments This article is taken from the M.Sc. dissertation of G. Mattos in the Programa de Pós-graduação em Ecologia of the 
Universidade Federal do Rio de Janeiro, Brazil. The authors express their deepest gratitude to all participants in the fieldwork, Dr. C.H.S. Caetano (UNIRIO) for critically reading early versions of the manuscript, and Dr. J.W. Reid for English language revision. Thanks are also due to Dr. Omar Defeo (UNDECIMAR), Dr. Heinz-Dieter Franke (AWI), and an anonymous reviewer for critical reading of and valuable suggestions on the final manuscript. The study was supported by the Fundação de Amparo à Pesquisa do Estado do Rio de Janeiro (FAPERJ), CT-Infra (Fundo Setorial de Infra-Estrutura) by MCT/CNPq (No. E-26/171.164/2006), and Coordenação de Aperfeiçoamento de Pessoal de Nível Superior (CAPES) postgraduate scholarships.

\section{References}

Abrahão JR, Cardoso RS, Yokoyama LQ, Amaral ACZ (2010) Population biology and secondary production of the stout razor clam Tagelus plebeius (Bivalvia, Selecurtidae) on a sandflat in southeastern Brazil. Zoologia 27(1):54-64

Ansell AD, McLusky DS, Stirling A, Trevallion A (1978) Production and energy flow in the macrobenthos of two sandy beaches in south west India. Proc R Soc Edinb Sect B 76:269-296

Arruda-Soares H, Schaeffrer-Novelli Y, Mandelli J Jr (1982) Berbigão Anomalocardia brasiliana (Gmelin, 1791), bivalve comestível da região da Ilha do Cardoso, Estado de São Paulo, Brasil: Aspectos biológicos de interesse para a pesca comercial. Bol Instit Pesca 9:21-38

Bergamino L, Lercari D, Defeo O (2011) Food web structure of sandy beaches: temporal and spatial variation using stable isotope analysis. Estuar Coast Shelf Sci 91:536-543

Boehs G (2000) Ecologia populacional, reprodução e contribuição em biomassa de Anomalocardia brasiliana (Gmelin, 1791) (Bivalvia: Veneridae) na Baía de Paranaguá, Paraná, Brasil. Curitiba. $\mathrm{PhD}$ thesis, Universidade Federal do Paraná, Brazil

Brey T, Clarke A (1993) Population dynamics of marine benthic invertebrates in Antarctic and subantarctic environments: are there unique adaptations? Antarct Sci 5:253-266

Brown AC (1996) Behavioural plasticity as a key factor in the survival and evolution of the macrofauna on exposed sandy beaches. Rev Chil Hist Nat 69:469-474

Cardoso RS, Mattos G, Caetano CHS, Cabrini TMB, Galhardo LB, Meireis F (2011) Effects of environmental gradients on sandy beach macrofauna of a semi-enclosed bay. Mar Ecol doi: 10.1111/j.1439-0485.2011.00457.x

Crisp DJ (1984) Energy flow measurements. In: Holme NA, McIntyre AD (eds) Methods for the study of marine benthos, vol 16 . Blackwell, Oxford, pp 284-372

Defeo O, Cardoso RS (2004) Latitudinal patterns in abundance and life-history traits of the mole crab Emerita brasiliensis on South American sandy beaches. Divers Distrib 10:89-98

Defeo O, McLachlan A (2005) Patterns, processes and regulatory mechanisms in sandy beach macrofauna: a multi-scale analysis. Mar Ecol Prog Ser 295:1-20

Defeo O, McLachlan A (2011) Coupling between macrofauana community structure and beach type: a deconstructive metaanalysis. Mar Ecol Prog Ser 433:29-41

DeLancey LB (1989) Trophic relationship in the surf zone during the summer at Folly Beach, South Carolina. J Coast Res $5: 477-488$

Denadai M, Amaral ACZ, Turra A (2004) Biology of a tropical intertidal population of Cerithium atratum (Born, 1778) (Mollusca, Gastropoda). J Nat Hist 38:1695-1710

Dexter DM (1992) Sandy beach community structure: the role of exposure and latitude. J Biogeogr 19:59-66
Domaneschi O (1979) Aspectos da biologia de Diplodonta punctata (Say, 1822) (Bivalvia: Lucinacea: Ungulinidae). Rev Nordestina Biol 2:21-25

Franke HD, Janke M (1998) Mechanisms and consequences of intraand interspecific interference competition in Idotea baltica (Pallas) and Idotea emarginata (Fabricius) (Crustacea: Isopoda): a laboratory study of possible proximate causes of habitat segregation. J Exp Mar Biol Ecol 227:1-21

Gaspar MB, Ferreira R, Monteiro CC (1999) Growth and reproductive cycle of Donax trunculus L. (Mollusca: Bivalvia) off Faro, southern Portugal. Fish Res 41:309-316

Gaspar MB, Pereira AM, Vasconcelos P, Monteiro CC (2004) Age and growth of Chamelea gallina from the Algarve coast (southern Portugal): influence of seawater temperature and gametogenic cycle on growth rate. J Moll Stud 70:371-377

Gayanilo FC Jr, Sparre P, Pauly D (1996) The FAO-ICLARM Stock Assessment Tools (FISAT) User's Guide. FAO Computerized Information Series (Fisheries) No. 8. FAO, Rome

Hall SJ (1994) Physical disturbance and marine benthic communities: life in unconsolidated sediments. Oceanogr Mar Biol 32:179-239

Hiroki K (1977) On the resistance of isolated bivalves Gill pieces to oxygen deficiency and hydrogen sulphide. Bol Fisiol Anim USP $1: 9-22$

Jaramillo E, Contreras H, Duarte C (2007) Community structure of the macroinfauna inhabiting tidal flats characterized by the presence of different species of burrowing bivalves in Southern Chile. Hydrobiologia 580:85-96

Lee SY (1996) Distribution pattern and interaction of two infaunal bivalves, Tapes philippinarum (Adams and Reeve) and Anomalocardia squamosa (Linnaeus) (Bivalvia: Veneridae). J Exp Mar Biol Ecol 201:253-273

Leonel RMV, Magalhães ARM, Lunetta JE (1983) Sobrevivência de Anomalocardia brasiliana (Gmelin, 1791) (Mollusca: Bivalvia) em diferentes salinidades. Bol Fisiol Anim USP 7:63-72

Lomovasky BJ, Brey T, Morriconi E, Calvo J (2002) Growth and production of the venerid bivalve Eurhomalea exalbida in the Beagle Channel, Tierra del Fuego. J Sea Res 48:209-216

McLachlan A, Brown AC (2006) The ecology of sandy shores. Elsevier, Amsterdam

Metaxatos A (2004) Population dynamics of the venerid bivalve Callista chione (L.) in a coastal area of the eastern Mediterranean. J Sea Res 52:293-305

Michaud E, Desrosiers G, Mermillod-Blondin F, Sundby B, Stora G (2005) The functional group approach to bioturbation: I. The effects of biodiffusers and gallery-diffusers of the Macoma balthica community on sediment oxygen uptake. J Exp Mar Biol Ecol 326:77-88

Michaud E, Desrosiers G, Mermillod-Blondin F, Sundby B, Stora G (2006) The functional group approach to bioturbation: II. The effects of the Macoma balthica community on fluxes of nutrients and dissolved organic carbon across the sediment-water interface. J Exp Mar Biol Ecol 337:178-189

Monti D, Frenkiel L, Mouëza M (1991) Demography and growth of Anomalocardia brasiliana (Gmelin) (Bivalvia: Veneridae) in a mangrove, in Guadeloupe (French West Indies). J Moll Stud $57: 249-257$

Mouëza M, Gros O, Frenkiel L (1999) Embryonic, larval and postlarval development of the tropical clam, Anomalocardia brasiliana (Bivalvia: Veneridae). J Moll Stud 65(1):73-88

Moura P, Gaspar MB, Monteiro CC (2008) Age determination and growth rate of a Callista chione. Aquat Biol 5:97-106

Narchi W (1972) Comparative study of the functional morphology of Anomalocardia brasiliana (Gmelin, 1791) and Tivela mactroides (Born, 1779) (Bivalvia, Veneridae). Bull Mar Sci 22:643-670 
Narchi W (1976) Ciclo anual da gametogênese de Anomalocardia brasiliana (Gmelin, 1791) (Mollusca: Bivalvia). Bol Zool $1: 331-350$

Pauly D, Munro JL (1984) Once more on the comparison of growth in fish and invertebrates. Fishbyte 2:21

Pauly D, Munro JL, Abad N (1995) Comparison of age structure and length-converted catch curves of brown trout Salmo trutta in two French rivers. Fish Res 22:197-204

Peterson CH, Black R (1993) Experimental tests of the advantages and disadvantages of high density for two coexisting cockles in a Southern Ocean lagoon. J Anim Ecol 62:614-633

Ricker WE (1975) Computation and interpretation of biological statistics of fish populations. Bull Fish Res Board Can 191:1-382

Rios EC (1994) Seashells of Brazil. Rio Grande, Brazil

Robertson AI (1979) The relationships between annual production: biomass ratios and lifespans for marine macrobenthos. Oecologia 38:193-202

Salvador L (2001) Malacofauna da região entremarés de praias de areia com fragmentos de rochas: Distribuição temporal e espacial; Dinâmica populacional e produção secundária de Anomalocardia brasiliana (Gmelin, 1791) e Corbula cubaniana (Orbigny, 1853). $\mathrm{PhD}$ thesis, Universidade Estadual Paulista, Brazil
Shaeffer-Novelli Y (1976) Alguns aspectos ecológicos e análise da população de Anomalocardia brasiliana (Gmelin, 1791) (Mollusca: Bivalvia), na praia do Saco da Ribeira, Ubatuba, Estado de São Paulo. PhD thesis, Universidade de São Paulo, Brazil

Sparre P, Ursin E, Venema S (1989) Introduction to tropical fish stock assessment. Part I. FAO Fish Tech Pap, Rome

Tumbiolo ML, Downing JA (1994) An empirical model for the prediction of secondary production in marine benthic invertebrate populations. Mar Ecol Prog Ser 114:165-174

Underwood AJ (1981) Techniques of analysis of variance in experimental marine biology and ecology. Oceanogr Mar Biol 19:513-605

Urban HJ, Campos B (1994) Population dynamics of the bivalves Gari solida, Semele solida and Protothaca thaca from a small bay in Chile at $36^{\circ} \mathrm{S}$. Mar Ecol Prog Ser 115:93-102

Wallner-Kersanach M, Lobo S, Silva EM (1994) Depuration effects on trace metals in Anomalocardia brasiliana (Gmelin, 1791). Bull Environ Contam Toxicol 52:840-847

Waters TF (1977) Secondary production in inland waters. Adv Ecol Res 10:91-164 